\title{
Çalışanların İş Tatmini Algıları İle İş Motivasyonu Düzeyleri Arasındaki İlişkinin Araştırılması
}

\author{
Ertuğrul KÖSE ${ }^{1}$
}

Özet

Araştırma çalışanların iş tatmini algılarıyla iş motivasyonu düzeyleri arasındaki ilişkiyi belirlemek amacıyla yapılmıştır. Çalışmada iki kavramsal yapı arasındaki ilişkileri belirlemek amacıyla alan yazından yararlanılarak likert tipi ölçekler kullanılmıştır. Söz konusu ölçüm araçları Türkiye'de kimyevi gübre sektöründe üretici olarak faaliyet gösteren işletmelerde görev yapan çalışan ve yönetici konumundaki beyaz yakalı 300 kişiye uygulanmış, katılımcılardan 251'i anketi cevaplayarak geri dönüş yapmış, 17 anket formu ise eksik veri içerdiğinden geçersiz sayılmıştır. Sonuç olarak, 234 anket formundaki veriler üzerinden istatistikî analizler yapılmıştır. Araştırma kapsamında temel hipotezin yanı sıra, alt hipotezlerde yaş, eğitim durumu ve iş deneyimi değişkenleriyle iş motivasyonu düzeyleri arasındaki ilişkiler istatistikî analiz aracılığıyla belirlenmiştir. Analiz sonucunda çalışanların iş tatmini algılarıyla iş motivasyonu düzeyleriyle arasında anlamlı, doğrusal ve pozitif yönlü bir ilişki olduğu görülmüştür. Demografik değişkenlerden yaş, eğitim durumu ve iş deneyimi ile motivasyon düzeyi arasında anlamlı bir ilişki belirlenememiştir.

Anahtar Kelimeler: İş Tatmini, İş Motivasyonu, Yaş, Eğitim, İş Deneyimi

\section{The Research On The Relationship Between Job Satisfaction Perceptions And Work Motivation Levels Of Employees}

\begin{abstract}
This research is done with the aim of identifiying the relationship between job satisfaction and work motivation concepts. Likert type scales to measure both conceptual structure were used in the study using available literature. Subjected measurement tools were applied for 300 people consisting of managers and white colour employees working in manufacturing firms of chemical fertilizer sector in Turkey. 251 participants of the survey replied by answering the survey. 17 of questionnaires are evaluated as invalid due to missing information they include. Finally statistical analyzes were performed with the data of 234 questionnaires. Within the scope of research, in addition to the main hypothesis, the relations between work motivation level and demographic variables of age, education and work experience were determined through analysis. As a result of the analysis, it has been concluded that there is a significant, linear and positive relationship between job satisfaction perceptions and work motivation levels of employees. On the other hand, no significant relationship were found between work motivation level and demographic variables of age, education level and work experience.
\end{abstract}

Keywords: Job Satisfaction, Work Motivation, Age, Education and Work Experience

1 Dr., Gübre Fabrikaları T. A.Ş., Risk, Süreç ve Kalite Yönetimi Müdürü, ertugrulkose@hotmail.com 


\section{Giriş}

Çalışanların işe ve işyerine yönelik tutumlarının bir yansıması olan iş tatmini örgütlerin başarısı için yöneticiler tarafından önemle dikkate alınması gereken faktörlerden biridir. İş tatmini kavramı, bireyin işi ile ilgili yaptığı değerlendirme sonucunda duyduğu memnuniyet veya memnuniyetsizlik durumunu ifade eder. Kişi değerlendirme yaparken beklentilerini ve elde ettiği kazanımları dikkate almakta, beklentilerini karşıladığı düzeyde de iş tatmini algılamaktadır. Beklentilerin karşılanamaması ise iş tatminsizliğine neden olur. İş tatmini yüksek olan bireyler rol aldıkları örgütlere ve iş arkadaşlarına karşı olumlu tutum ve davranışlar sergileyerek kurumsal performansın artışına katkıda bulunurlar. Düşük iş tatminine sahip olan çalışanlar ise, devamsızlık, iş yavaşlatma ve iş değiştirme eğilimine yönelme gibi işletmenin faaliyetlerini olumsuz etkileyebilecek yaklaşımlarda bulunulabilirler. $\mathrm{Bu}$ nedenle, işletme yöneticilerinin çalışanların beklentilerini karşılamaya katkıda bulunacak ve iş tatminini artıracak uygulamaları sürekli gözden geçirmeleri yararlı olacaktır.

Bireysel ve örgütsel hedeflere ulaşılabilmesi için çalışanların motive edilmesi gerekir. Motivasyon kavramını, bireyin belirli ihtiyaç veya hedeflerini gerçekleştirmek için harekete geçme, yönelme ve sonuç alıncaya kadar gerekli çabayı sürdürme süreci olarak tanımlayabiliriz. Motivasyon sürecinde içsel ve dışsal faktörler etkili olmaktadır. İş yaşamında motivasyonun amacı, çalışanların başarı düzeyini yükselterek etkinlik ve verimlilik çerçevesinde kurumsal hedeflere ulaşılmasını sağlamaktır. Yöneticinin de başarı olasıllğı büyük ölçüde ekibini örgütsel hedeflere dönük motive edebilmesine bağlıdır. Hedeflenen başarı düzeyinin yakalanabilmesi için çalışanlar maddi ve diğer motivasyon araçları ile desteklenmelidir.

İş tatmini ve iş motivasyonu ilişkisi yazında çok sayıda araştırmacı tarafından ele alınmıştır. Ancak, ulusal yazındaki araştırmaların sınırlı düzeyde kaldığı ve çalışmaların ağılıklı olarak eğitim, turizm ve sağlık sektörlerindeki iş görenler üzerine odaklandığı görülmektedir. $\mathrm{Bu}$ araştırma ile yazındaki bilgi birikiminin zenginleştirilmesine katkı sağlanması hedeflenmektedir.

$\mathrm{Bu}$ çalışmada çalışanların iş tatmini algılarıyla iş motivasyonu düzeyleri arasındaki ilişkinin araştırılması amaçlanmıştır. Bu doğrultuda araştırma, belirtilen değişkenler arasındaki ilişkilerin ve çeşitli demografik değişkenler açısından iş motivasyonu düzeyinin farklılaşıp farklılaşmadığının ortaya çıkarılmasını hedeflemektedir. Araştırma, Türkiye'de kimyevi gübre sektöründe üretici olarak faaliyet gösteren işletmelerde görev yapan beyaz yaka çalışan ve yöneticileri kapsamaktadır. 


\section{Literatür}

\section{1. İş Tatmini}

İş tatmini, işletme yönetimi, psikoloji ve örgütsel davranış gibi alanlarda çok sayıda araştırmacı tarafından incelemeye konu edilmiş bir kavramdır. Çalışanın İş tatmini bireyin işi ile ilgili duygu, düşünce, yargı, tutum ve algılarını yansıtır. İş tatmini, çalışanın işine yönelik memnuniyet düzeyini gösterir. İş tatmini kavramı ilk olarak Hoppock (1935) tarafından dile getirilmiştir. Hoppock'a göre iş tatmini bireyin iş çevresine yönelik memnuniyet algısıdır. Weiss iş tatminini "bireyin işi hakkında yaptığ1 olumlu veya olumsuz değerlendirme" şeklinde tanımlamıştır (Weiss, 2002: 175). Aziri’ye göre iş tatmini, işin kişinin maddi ve psikolojik ihtiyaçlarını ne düzeyde karşıladığına dair algısını ifade eder (Aziri, 2011: 78). İş tatmini, kişinin işinden ne düzeyde memnun olduğuna dair algısını ortaya koyar. İşe yönelik pozitif, olumlu duygu ve tutumlar iş tatminine işaret ederken, olumsuz değerlendirmeler ise, iş tatminsizliğini gösterir.

İş tatmini ile ilgili kuramsal yaklaşımların temeli Maslow'un "ihtiyaçlar hiyerarşisi”" ve Herzberg' in "çift faktör” teorisine kadar uzanmaktadır. Motivasyon kuramları bireylerin güdülenmesine odaklanmakla birlikte iş tatmini kavramını da açıklamaya çalışan önemli yaklaşımlardır. İhtiyaçlar hiyerarşisi kuramına göre iş tatminini belirleyen temel faktörlerden biri iş görenin ihtiyaçlarının karşılanıp karşılanmamasıdır. Birey ihtiyaçları karşılandığ ölçüde işinden doyum elde edecektir. İş tatmini konusuna açıklama getiren yaklaşımlardan bir diğeri de Herzberg'in çift faktör teorisidir. Bu yaklaşıma göre, tanınma, kariyer imkânları, sorumluluk, başarma ve işin kendisi gibi motivasyon etmenleri iş görenin doyumuna katkıda bulunurken, ücret, kişiler arası ilişkiler, çalışma koşulları, şirket politikaları, statü ve denetim gibi hijyen faktörler ise tatminsizliği engellemektedir. İş tatmini ancak motivasyon faktörlerinin karşılanması ile sağlanabilir, hijyen faktörler ise bulunmamaları halinde tatminsizliğe yol açarken, varlıkları ise iş tatminin gerçekleşmesi için yeterli değildir (Doğan \& Aslan, 2018: 114; Dugguh \& Dennis, 2014: 12). Kuramsal katkı yapan araştırmacılardan Wroom, iş tatmininin sağlanmasında bireylerin sosyal ihtiyaçlarının karşılanmasında farklılıkların dikkate alınması gerektiğini vurgulamıştır. Adams ise, "Eşitlik Kuramı”nda iş görenlerin aynı düzeyde ve benzer koşullarda çalıştıkları kişilerle kendilerini karşılaştırdıklarını, bu doğrultuda da elde ettikleri ücret ve sunulan imkânlar açısından eşit olup olmadıklarına bağlı olarak iş tatmini ya da tatminsizliğinin ortaya çıktığını ileri sürmektedir. Adams'ın değerlendirmesine benzer bir yaklaşım Salancik ve Pfeffer (1977) tarafından geliştirilen "Kişilerarası Karşılaştırma Kuramı”nda da dile getirilmiştir. Salancik ve Pfeffer'e göre bireyin iş tatmini kendisine benzer konumda görev yapan diğer çalışanlarla yaptığı karşılaştırmalar sonucunda oluşmaktadır. Diğer bir ifadeyle, iş gören diğerleri ile kendisini karşılaştırmasına bağlı olarak iş tatmini ya da tatminsizliği yaşamaktadır (Eğinli, 2009: 37).

İş tatmini üzerinde belirleyici olan faktörler araştırmacılar tarafından farklı boyutlarda ele alınmıştır. İş tatminini ölçmek için bazı araştırmacılar iş karakteristiklerine odaklanırken bazıları ise 
genel iş doyumu üzerinde durmuşlardır. Weiss ve arkadaşları (1967) iş tatmini kavramını içsel ve dışsal doyum boyutlarında ele almışlardır. İçsel tatmin boyutunda işin kendisi, özerklik, çeşitlilik, statü, ahlaki değerler, güvenlik, sosyal hizmetler, otorite yetenek, sorumluluk, iş arkadaşları ve başarı değişkenleri dikkate alınmıştır. Dışsal tatmin boyutunda ise, çalışma koşulları, şirket politikaları, yöneticiler, ücret, etkinlik, terfi imkânları, insan ilişkileri ve ödül değişkenleri değerlendirmeye alınmıştır (Kaya, 2007: 358-359). Smith, Kendall ve Hulin (1969) iş tatminini işin kendisi, ücret, denetim, iş arkadaşları ve terfi fırsatları boyutlarında değerlendirmişlerdir. Kalleberg (1977) de iş tatmini kavramını Weiss ve arkadaşlarının yaklaşımına benzer bakış açısıyla içsel ve dışsal doyum çerçevesinde incelemiştir. İşin ne düzeyde ilginç olduğu ve çalışan tarafından idare edilebildiği içsel doyum ile ilgilidir. Kalleberg dışsal tatmini ise kariyer imkânları, iş arkadaşlarıyla ilişkiler, finansal olanaklar, kaynak yeterliliği boyutlarında incelemiştir (Seifert \& Umbach, 2008: 359). Spector, iş tatminini ücret, terfi, yönetme, yan haklar, ödüller, çalışma koşulları, iş arkadaşları, işin kendisi ve iletişim olmak üzere dokuz alt boyutta ele almıştır (Spector, 1985: 702).

İş tatmini üzerinde işin özellikleri, bireysel farklılıklar ve örgütsel faktörler etkili olmaktadır. Beceri çeşitliliği, işin önemi, özerklik, görev bütünlüğü ve geri bildirim iş doyumunu etkileyen iş özelliklerinden bazılarıdır. Beceri çeşitliliği, işin yürütülebilmesi için bireyin taşıması gereken yetenek ve beceriler bütünüdür. İşin önemi, yapılan faaliyetlerin örgütteki diğer çalışanların veya başkalarının yaşamlarına etkide bulunma olanağıdır. Özerklik, yapılacak işi planlama ve belirlenen hedefe ulaşmak için kullanılabilecek araçları seçme konusunda iş görene tanınan serbestlik ve özgürlüğün derecesini ifade eder. Görev bütünlüğü, işin tanımlanan tamamlanma aşamalarında iş görene katılımda bulunma imkânı sağlanmasıdır. Geri bildirim, iş görene işi nasıl yaptığı konusunda bilgi verilmesidir (Dugguh \& Dennis, 2014: 15; Dalkrani \& Dimitriadis, 2018: 17).

İş tatmini üzerinde bireysel özellikler de belirleyici olmaktadır. İş tatminini etkileyen bireysel faktörler arasında yaş, cinsiyet, eğitim düzeyi, statü, kişilik ve iş deneyimi gibi demografik değişkenler yer almaktadır. Yapılan araştırmalarda yaşlı çalışanların gençlere göre daha yüksek iş tatmini elde ettikleri belirlenmiştir. Bazı araştırmalarda kadınların erkeklere göre daha yüksek iş tatmini yaşadıkları görülmesine karşın, bazı çalışmalarda da erkeklerin iş doyumlarının daha yüksek olduğu sonucuna varılmıştır. Diğer demografik değişkenlerle iş tatmini arasında farklı sonuçlar elde edilmiştir (Seyrek \& Kavak, 2016: 15).

Örgütsel faktörler iş tatmini üzerinde etkili olmaktadır. İş tatminini etkileyen örgütsel faktörler arasında işyeri koşulları, şirket politikaları, örgüt iklimi, işin niteliği, ücret, kişiler arası ilişkiler, yönetim tarzı, esneklik, iletişim, denetim biçimi, kariyer imkânları ve çalışma arkadaşları yer alır (Eroğluer, 2011: 124; Alonderiene \& Modesta , 2016: 144). 
İş tatminin birey ve örgütler açısından önemli sonuçları bulunmaktadır. Günlük yaşamının önemli bir bölümünü iş yaptığı örgütte geçiren çalışanın tatmin düzeyi, özel yaşamını ve sağlığını olumlu ya da olumsuz yönde etkileme potansiyeline sahiptir. Yapılan araştırmalara göre iş tatmini çalışanların işe katılım konusunda istekliliğini, yaratıcı düşünme eğilimini ve iş performansını olumlu etkilemektedir. İş görenlerin yüksek düzeyde iş tatmini algısına sahip olmaları örgütsel bağl1lıklarının artmasına, iş yerine karşı daha olumlu yaklaşım sergilemelerine, sağlı sorunlarının azalmasına ve tükenmişlik algılarının zayıflamasına katkıda bulunmaktadır (Karaman, 2018: 68). İş tatmini algısının düşük olması ise, çalışanın işine yabancılaşmasına, işten ayrılma eğilimine, örgütsel bağl1lı̆ın azalmasına, çatışma ve devamsızlık gibi olumsuz sonuçlara neden olmaktadır (Eroğluer, 2011: 124; Saracel, Taşseven, \& Kaynak, 2016: 55) .

İş tatmini ve iş motivasyonu birbiriyle yakından ilişkili olan iki kavramdır. Bu iki kavram arasındaki ilişki karşılıklı etkileşime dayalıdır. İş tatmini bireylerin iş motivasyonu üzerinde etkili olurken, iş motivasyonu da çalışanların iş tatmini algılarında belirleyici olur. Alan yazında iş tatmini ile iş motivasyonu arasındaki karşılıklı etkileşimi destekler nitelikte çok sayıda araştırma bulunmaktadır (Balıbey \& Öndaş, 2018, s. 178; Elias, William, \& Chet, 2012, s. 459; Sultan, 2012, s. 19; Springer, 2011, s. 38). İş tatmini algısı olumlu olan bireylerin iş motivasyonu düzeylerinin de yüksek olması beklenir.

\section{2. İş Motivasyonu}

Motivasyon (güdülenme), biyoloji, sosyoloji, yönetim ve psikoloji gibi bilim dallarında birçok araştırmacı tarafından inceleme konusu yapılmış olan karmaşık bir kavramdır. Güdülenme, bireyin davranışlarını doğrudan etkileyen biyolojik, psikolojik, sosyal ve bilişsel faktörlerle ilişkilidir. Motivasyon, kişinin istek veya ihtiyaçlarını gidermek için harekete geçecek düzeyde isteklenmesidir. Motivasyon, bireyi bir hedefe yönelik harekete geçiren süreçler bütünü olarak tanımlanabilir (Sdrolias ve diğerleri, 2014: 84). Ryan ve Deci’ye göre ise, motivasyon kişinin bir amaç için hareket geçmesidir (Ryan \& Deci, 2000: 54).

İş motivasyonu çalışan ile iş çevresi arasındaki etkileşimleri yansıtır. İş motivasyonu, örgütsel hedeflerin yakalanması yönünde iş görenin çaba gösterme ve sürdürme konusunda ne düzeyde istekli olduğu ile ilgilidir (Li ve diğerleri, 2014: 2). Pinder iş motivasyonunu "işle ilgili davranışı başlatma, şekline, yönüne, yoğunluğu ve süresine karar verme noktasında bireyin içsel güdülenmesinin yanı sıra dışsal faktörlerin tetiklediği bir dizi enerjik güçler” şeklinde tanımlamıştır. Tanımda yer alan enerjik güçler; ihtiyaçlar, itici faktörler, güdüler ve dışsal unsurların çoklu yapısını ifade etmektedir (Pinder, 2014: 11).

Motivasyonla ilgili alan yazınına baktığımızda bu konuda çok sayıda kuram geliştirildiği görülmektedir. Motivasyon teorileri, bireyleri motive eden faktörlerin belirlenmesi amacıyla geliştirilmiş kuramsal yaklaşımlardır. Bu modellerden bazıları kişilerin güdülenmesinde bireysel 
ihtiyaçların bir ifadesi olan güdülere, dolayısıyla kişinin içsel faktörlerine odaklanırken, diğerleri ise, teşvikler gibi dışsal faktörleri inceleme konusu yapmışlardır. Bu teorik yaklaşımlar kapsam ve süreç kuramları olmak üzere iki grupta sınıflandırılmıştır. Kapsam teorilerinin odak noktasını bireysel ihtiyaçlar oluştururken, süreç kurumlarında ise dışsal ve bilişsel faktörler üzerinde durulmuştur (Gökkaya \& Türker, 2018:13). Maslow'un ihtiyaçlar hiyerarşisi, Alderfer'in ERG teorisi, Mc Clelland'ın başarma ihtiyacı ve Herzberg'in çift faktör kuramı öne çıkan kapsam teorileri arasındadır. Dışşal ve bilişsel faktörlere odaklanan süreç yaklaşımlarından en çok bilinenleri ise Skinner'in pekiştirme teorisi, Vroom'un beklenti kuramı, J. Stacy Adams'1n eşitlik teorisi ve Edwin Locke'ın amaç belirleme kuramıdır (Çivilidağ \& Şekercioğlu, 2017: 147; İbicioğlu, Özdaşlı, Dalğar, \& Yılmaz, 2013: 96).

Çalışanın iş motivasyonunda hem içsel hem de dışsal faktörler etkili olur. İçsel motivasyon faktörleri, işin doğasıyla ilgili olup, işin içeriğinden kaynaklanmaktadır. Çalışan açısından işin ilgi çekici ve zorlayıcı olması, işte bağımsızlık, işin önemi, sorumluluk, çeşitlilik, yaratıcılık, iş görenin yeteneklerini kullanabilme firsatı ve performansla ilgili tatmin edici geri bildirim gibi unsurlar içsel motivasyon faktörlerinden bazılarıdır. Dışsal faktörler arasında ise ücret, parasal ödüller, işyeri özellikleri ve takdir edilme yer alır (Ertürk, 2016: 3).

İş motivasyonu kavramına açıklama getiren kuramsal yaklaşımlarda biri de Ryan ve Deci tarafından geliştirilen öz-belirleme (Self-determination theory) kuramıdır. Öz-belirleme kuramının merkezinde özerk ve kontrollü motivasyon ayrımı yer alır. Özerklik, kendiliğinden ve isteyerek bir eyleme geçme ve seçimde bulunmayı ifade eder. İş görenler iş tatmini elde ettiklerinde ve görevlerinin önemli olduğuna kanaat getirdiklerinde yüksek motivasyon düzeyine ulaşırlar. Bu bağlamda içsel motivasyon bir özerk motivasyon örneğidir. Eğer bireyler bir işi kendilerini değerli hissetmek veya suçluluk ve endişe duymak gibi olumsuz duygulardan kaçınmak, tehdit, ödül veya içsel/dışsal baskı nedeniyle gerçekleştiriyorlar ise, kontrollü motivasyon durumu söz konusudur. Dişşal güdülenme kontrollü motivasyona bir örnektir (Gagné \& Deci, 2005: 333-334). Yapılan araştırmalarda özerk motivasyonun psikolojik olarak kendini iyi hissetme, iş tatmini ve örgütsel bağl1lıkla pozitif yönlü; kontrollü motivasyonun da işkoliklik, tükenmişlik ve işten ayrılma eğilimi ile olumlu yönde ilgileşime sahip olduğu belirlenmiştir (Fernet, Austin, \& Vallerand, 2012: 215).

Öz-belirleme kuramı iş motivasyonu kavramına çok boyutlu bir yaklaşım getirmektedir. $\mathrm{Bu}$ kurama göre, üç motivasyon kategorisi bulunmaktadır: (1) Motive olamama, (2) içsel motivasyon ve (3) dışsal motivasyon. Motive olamama, bir aktiviteye yönelik motivasyon eksikliğini ifade eder. Bireyler kapasite yetersizliği algısı, önerilen stratejinin istenilen sonucu getirmeyeceği inancı, istenen çabayı sergilemede isteksizlik ve başarılı olamayacakları düşüncesi nedeniyle motive olmakta zorlanabilirler. Motive olamama durumunda birey kendi iyi hissetmemekte ve düşük performans sergilemektedir (Rigby \& Ryan, 2018: 136). İçsel motivasyon, ilginç ve keyifli olduğu için bireyin bir eylemi kendi 
isteğiyle gerçekleştirmesini ifade eder. İçsel güdülenme, harekete geçmenin farklı sonuçlarından çok onun özündeki tatmine dayalı yapılan bir eylem olarak tanımlanmaktadır. İçsel motive olan birey kışkırtma, baskı veya ödüller gibi dışsal faktörleri dikkate alarak harekete geçmez. Dışsal motivasyon ise, ödül elde etme, onaylanma, eleştirilme veya cezalandırılmadan kaçınma, öz saygı kazanma veya kişisel olarak değerli bir hedefe ulaşma gibi nedenlerle bir eyleme geçmek şeklinde tanımlanabilir. Dışsal motivasyonda davranış sonrasında elde edilmesi beklenen sonuçlar güdüleyici faktör konumundadır (Ryan \& Deci, 2000: 56-60; Gagné ve diğerleri, 2014: 2).

Öz-belirleme kuramında dışsal motivasyon dört farklı boyutta ele alınmaktadır. Birinci boyutta dışsal düzenleme yer alır. Dışsal düzenleme, bir eylemin ödül kazanma veya cezadan kaçınma amacıyla yapılmasını ifade eder. İş göreni harekete geçiren davranış tam olarak içselleştirilememiştir. İkinci boyut olan kendine yansıtma, egonun dikkate alınması veya suçluluk duygusu yaşamak istememe gibi öz değerlendirme kısıtları nedeniyle davranışın düzenlenmesidir. Bu yaklaşım kısmi içselleştirmeyi yansıtır. Diğer bir boyut içsel düzenlemedir. İçsel düzenlemede birey faaliyetin değerini veya anlamını kendisiyle özdeşleştirerek düzenlemekte ve harekete geçmektedir. Eyleme geçmede algılanan anlam veya aktivitenin kişisel çıkarlarla ilişkisi önem arz eder. Son boyut olan bütünleştirme, bir eylemin değerini kişisel davranışların işlevi ve öz benliğin bir parçası olarak özdeşleştirmedir. Bütünleştirme dışsal motivasyonun en özerk şeklidir. Bütünleştirme boyutunda dışsal güdülenen davranışlar özerk motivasyona dönüşmektedir. Ancak, birey eyleme geçerken kendiliğinden değil, faaliyetin kişisel çıarlara getireceği araçsal faydayı gözettiğinden bütünleştirme bir içsel motivasyon şekli değildir (Gagné ve diğerleri, 2010: 629; Sdrolias ve diğerleri, 2014: 86-87).

Öz-belirleme kuramına göre çalışanlar özerk motivasyona sahip olduklarında işlerinde daha iyi performans ortaya koymaktadırlar. İç ve dış baskı aracılığıyla kontrollü motive olduklarında ise iş gören daha düşük düzeyde başarı göstermektedirler. İş görenler özerklik, yetkinlik ve bağl1lık gibi psikolojik ihtiyaçları karşılandığında özerk bir şekilde kendilerini motive hissetmektedirler (Jungert, Van den Broeck , Schreurs, \& Osterman , 2018: 4). Araştırmada çalışanların iş motivasyonu düzeyleri özbelirleme kuramı çerçevesinde ele alınmıştır.

\section{Yöntem Bilim}

Çalışanların iş tatmini algılarıyla iş motivasyonu düzeyleri arasındaki ilişkilerin incelendiği bu araştırmada tanımlayıcı ve sonuç çıkarıcı istatistiklerden yararlanarak katılımcıların iki kavramsal yapıya yönelik cevapları analiz edilerek değerlendirilmiştir. Hipotez testlerinden yararlanılarak iki kavramsal yapı arasındaki ilişkiler; iş tatmini ile iş motivasyonu ve demografik değişkenlerle iş motivasyonu arasındaki ilişkiler istatistiki yöntemlerle test edilerek belirlenmeye çalışılmıştır.

Araştırmanın hipotezleri aşağıdaki şekilde belirlenmiştir:

$\boldsymbol{H}_{I}$ : Çalışanların iş tatmini algılarıyla iş motivasyonu düzeyleri arasında anlamlı, doğrusal ve pozitif yönlü bir ilişki vardır. 
$\boldsymbol{H}_{2}$ : Yaş değişkenine göre grupların iş motivasyonu ortalama puanları arasında anlamlı bir farklılık vardır.

$\boldsymbol{H}_{3}$ : Eğitim değişkenine göre grupların iş motivasyonu ortalama puanları arasında anlamlı bir farkl111k vardır.

$\boldsymbol{H}_{4}$ : İş deneyimi değişkenine göre grupların iş motivasyonu ortalama puanları arasında anlamlı bir farkl11ık vardır.

\subsection{Anakütle ve Örneklem}

İş görenlerin iş tatmini algılarıyla iş motivasyonu düzeyleri arasındaki ilişkiselliği belirlemeye yönelik olan araştırma istatistiksel veri toplanmasına ve bu verilerin analizine dayanmaktadır. Araştırma kapsamında, Türkiye'de kimyevi gübre sektöründe üretici olarak faaliyet gösteren işletmelerde görev yapan beyaz yakalı çalışan ve yöneticilerden "anket" yöntemiyle veri toplanmıştır. Araştırma evrenini İstanbul, İzmir, Bursa, Balıkesir, İzmit ve Adana'daki beyaz yakalı çalışanlar oluşturmaktadır. Araştırma kapsamındaki firmalarda beyaz yakalı çalışan sayısı 650'dir. Araştırma için 300 anket formu tesadüfi yöntemle belirlenen işletmelerde görev yapan yönetici ve iş görenlere dağıtılmıştır. Örneklemin ana kütleyi temsil oranı \% 46 'dır.

Anket formları iki ayrı metottan yararlanılarak cevaplandırılmıştır. Birinci yöntemde anketler araştırmacının bizzat katılımcılarla yüz yüze görüşmesi suretiyle gerçekleştirilmiştir. Bu şekilde 73 anket temin edilmiştir. İkinci yöntemde anket formu e-mail ekinde belirlenen hedef kitledeki kişilerin elektronik postalarına gönderilerek cevaplamaları istenmiştir. İkinci yöntemle 178 anket formu elde edilmiştir. Anketin amacı ve önemi ile ilgili bilgi verilen katılımcıların yanıtlama süresince ankete ilişkin sorularına cevap verilmiştir. Uygulanan veri edinim metotlarının tümünde anket katılımcılarına işletme bilgisinin, katılımcılara ilişkin bilgilerin ve anket ifadelerine verilen yanıtların gizli tutulacağı bilgisi verilmiştir. Ankete katılan yönetici ve iş görenlere anketin eksiksiz ve hatasız, örgütsel pratikler dikkate alınarak cevaplandırılması gerektiği bilgisi verilmiştir. Dağıtılan 300 anket formundan 251'i geri dönmüş, 17'si eksik veri içerdiğinden geçersiz kabul edilerek analiz ve değerlendirmeye alınmamıştır. 234 anket formu analiz ve değerlendirmeye alınmıştır. Anketlerin cevaplanma oranı $\% 84$ 'dür.

\section{2. Ölçüm Araçları ve Uygulaması}

Araştırmada, iş tatmini algısı ile iş motivasyonu düzeyini ölçmeye yönelik iki farklı ölçüm aracından yararlanılmıştır. Araştırmada yararlanılan anket formu üç bölümden oluşmaktadır. İlk bölümde katılımcılara yönelik statü, yaş, cinsiyet, öğrenim durumu ve çalışma süresi gibi demografik sorular; ikinci bölümde katılımcıların iş tatmini algılarını ölçmeye yönelik "Minnesota İş Tatmini Envanteri” kısa formundan yararlanılmıştır. İş tatmini kavramsal yapısı bu ölçekte 2 boyut ve 20 ifadeden oluşmaktadır. İlk boyut olan içsel tatmin boyutunda 12; dışsal tatmin boyutunda sekiz ifade 
yer almaktadır. İki madde ise iş tatmini genel puanlarının hesaplanmasında değerlendirmeye dâhil edilmiştir. İfadelere 5 dereceli likert tipi ile yanıt aranmıştır. Ölçekte; (1) Hiç katılmıyorum, (2) Katılmıyorum, (3) Kararsızım, (4) Katılıyorum, (5) Tamamen Katılıyorum seçenekleri yer almıştır. Üçüncü bölümde ise, iş motivasyonu düzeyini ölçmeye yönelik ifadelere yer verilmiştir. İş motivasyonu düzeyini ölçmek için Gagné, Forest, Gilbert, Aubé, Morin Malorni ve diğerleri tarafından 2010 yılında geliştirilen ve Çivilidağ (2017) tarafından Türkçe'ye uyarlanan "Çok Boyutlu İş Motivasyonu" ölçeği'nden yararlanılmıştır. Bu ölçek kapsamında altı boyut ve 19 ifade yer almaktadır. Söz konusu ölçek; motive olamama, dışsal düzenleme-maddesel, dişsal düzenleme sosyal, içsel düzenleme, kendine yansıtma ve içsel motivasyon alt boyutlarından oluşmaktadır. Ölçüm aracındaki ifadelere 5 dereceli likert tipi ile yanıt aranmıştır. Ölçekte; (1) Hiç katılmıyorum, (2) Katılmıyorum, (3) Kararsızım, (4) Katılıyorum, (5) Tamamen Katılıyorum seçenekleri yer almıştır.

Araştırmanın bağımlı değişkenini iş motivasyonu oluşturmaktadır. Bağımsız değişken ise iş tatmini algısıdır. Faktör analizi sonrasında iş tatmini ölçeği iki boyutta 20 madde, çok boyutlu iş motivasyonu ölçeği ise beş boyutta 19 maddeli ölçüm aracı olarak şekillenmiştir. Analize her iki ölçek için belirlenen faktöriyel yapılar ile devam edilmiştir.

Verilerin analizinde SPSS v.23, FACTOR v.10.5.03 ve Amos v.21 istatistik programlarından yararlanılmıştır. Tanımlayıcı ve hipotez testlerinin analizinde SPSS; açıklayıcı faktör analizinde FACTOR programı ve doğrulayıcı faktör analizinde ise, Amos v.21 paket programı kullanılmıştır.

\subsection{Uygulanan İstatistikî Analizler}

Araştırmada, iş tatmini tahmin değişkeni, iş motivasyonu ise sonuç değişkeni olarak tanımlanmıştır. Araştırmanın temel hipotezi "İş tatmini algısı yüksek olan çalışanların iş motivasyonu düzeylerinin de yüksek olacağı” şeklinde belirlenmiştir. İş tatmini ile iş motivasyonu ölçeklerinde ölçek puanları ilgili maddelerin aritmetik ortalamaları hesaplanarak bulunmuştur. Araştırmanın temel hipotezi için korelasyon analizi, iş motivasyonu ile demografik değişkenler arasındaki ilişkilerin belirlenmesi için ise, ANOVA analizine başvurulmuştur.

\section{Bulgular}

Araştırmanın bulgularına katılımcılara ilişkin tanımlayıcı istatistikler, boyutsallık analizi bulguları, güvenilirlik, ölçeklerin geçerliliğine ilişkin bulgular ve hipotez testlerinin sonuçları başlıkları altında yer verilmiştir.

\subsection{Tanımlayıcı İstatistikler}

Katılımcılara ilişkin cinsiyet, statü, yaş, eğitim durumu ve çalışma süreleri değişkenlerinden oluşan demografik verilerin sıklık ve yüzde dağılımları hesaplanarak elde edilen bulgular şu şekildedir: 
Araştırmaya katılanların \% 76,5'i (179 kişi) erkek, \% 23,5'i (55 kişi) ise kadınlardan oluşmuştur. Katılımcıların \% 60,3’ü (141 kişi) yönetici olmayan, \% 39,7'si (93 kişi) yöneticidir. Katılımcıların büyük bir çoğunluğunun erkek ve yönetici olmayanlardan oluştuğu anlaşılmaktadır.

Yaş değişkenine göre, katılımcıların \% 21,4'ünün (50 kişi) 18-29 yaş grubunda; \% 43,6'sının (102 kişi) 30-39 yaş gurubunda;\%24,8'inin (58 kişi) 40-49 yaş grubunda; \%10,3'ünün (24 kişi) ise, 5059 yaş grubunda yer aldığı görülmektedir. Katılımcıların büyük bir kısmının (\%65) 18-39 yaş aralığında yer aldığı, bu nedenle anketi cevaplayanların nispeten genç kişilerden oluştuğu sonucuna varılmıştır.

Öğrenim durumu değişkenine göre, katılımcıların \%8,1’i (19 kişi) lise; \%6,4'ü (15 kişi) ön lisans; \%62,8’i (147 kişi) lisans ve \%22,6’s1 (53 kişi) lisansüstü öğrenim düzeyine sahiptir.

İş deneyimi değişkeni incelendiğinde, anketi cevaplayanların \%21,4'ünün (50 kişi) 0-5 yıl; \%23,1'inin (54 kişi) 6-10 yıl; \%19,7'sinin (46 kişi) 11-15 yı1; \%15,4'ünün (36 kişi) 16-20 yıl ve \%20,5'inin (48 kişi) 21 yıl ve üzeri iş deneyimine sahip olduğu görülmektedir.

\subsection{Boyutsalık Analizleri, Güvenilirlik ve Geçerlilik}

Boyutsallık analizi, çok boyutlu değişken kümesi üzerinde ortak ilişkisel bağlantılara sahip olan değişkenleri gruplandırmak ve böylece boyutlarını belirlemek üzere uygulanmaktadır. Faktör analizi öncesinde örneklemin yeterlilik ve uygunluğunu belirlemek için SPSS v.23 programı aracılı̆̆ıyla Kaiser Meyer Olkin (KMO) ve Barlett küresellik test istatistiği hesaplanmıştır. Verilerin faktör çıkarmak için yeterli ve uygun olduğuna karar verebilmek için KMO katsayısının 0,60'dan büyük; Barlett test istatistiği değerinin anlamlı ve determinant göstergesinin de sıfirdan büyük olması gerekir (Beavers ve diğerleri, 2013: 4). Analiz sonucunda iş tatmini ölçeğine ilişkin Kaiser Meyer Olkin (KMO) test sonucu 0,843; Barlett istatistik test sonucu $X^{2} 1749,8(d f=190 ; p=0,00)$ ve iş motivasyonu ölçeğine ilişkin Kaiser Meyer Olkin (KMO) test sonucu 0,823; Barlett istatistik test sonucu $X^{2} 2231,2(d f=171 ; p=$ $0,00)$ şeklinde belirlenmiştir. Bu bulgular çerçevesinde örneklemin faktör analizini gerçekleştirmek için yeterli düzeyde ve uygun olduğu sonucuna varılmıştır.

Araştırmada "İ̧̧ Tatmini” ve "İş Motivasyonu" ölçekleri içerisinde bulunan maddeler için açıklayıcı faktör analizi yöntemi kullanılmıştır. Açıklayıcı faktör analizi (AFA) için "Factor 10.5.03" programından yararlanılmıştır. AFA kapsamında maddeler arası korelasyon değerleri İş Tatmini ölçeğinde 0,15 ile 0,71 ; İş Motivasyonu ölçeğinde ise 0,12 ile 0,72 arasında çıkmıştır. İki kavramsal yap1 arasındaki korelasyon değeri ise 0,577 olarak belirlenmiştir. Korelasyon değerleri belirlenirken polikorik korelasyon analizi; faktör sayısını belirlemek için ise, paralel analiz yöntemi uygulanmıştır. Likert tipi ölçüm araçları için Pearson korelasyon analizi yerine polikorik veya tetrakorik korelasyon analizi yöntemine de başvurulabilmektedir (Ledesma \& Valero-Mora, 2007, s. 4-5). Paralel analiz yaklaşımı Horn tarafından geliştirilmiş bir yöntem olup, diğer tekniklere göre faktör sayısının belirlenmesinde daha doğru sonuç verdiği ileri sürülmektedir (Matsunaga, 2010, s. 102). Bireysel faktör 
ağırlığının tespitinde 0,40 değeri temel alınmıştır. Yapılan açıklayıcı faktör analizi sonucunda İş tatmini kavramsal yapısının iki boyutlu, iş motivasyonunun ise beş faktörlü bir yapıya sahip olduğu görülmüştür. Faktöriyel yapı belirlendikten sonra ölçüm araçları ve veriler için güvenilirlik analizi yapılmıştır.

Güvenilirlik analizi bağlamında maddeler arası korelasyon değerleri, yarıya bölme ve iç tutarlı1ık gibi farklı yöntemlere başvurulmaktadır. Güvenilirlik analizi için başvurulan yöntemlerden bir diğeri de iç tutarlılık yaklaşımıdır. İç tutarlılık güvenilirliğini belirlemek için en çok Cronbach alfa güvenilirliğinden yararlanılmaktadır. Ölçüm araçlarına ilişkin güvenilirlik katsayıları ayrı ayrı hesaplanmış olup, daha sonra sonuçlar Tablo 1'de bir araya getirilmiştir.

Tablo 1. Ölçeklere ilișkin Güvenilirlik Değerleri

\begin{tabular}{|l|c|c|}
\hline & ifade sayısı & Cronbach alfa \\
\hline iş Tatmini Ölçeği & 20 & 0,88 \\
\hline İçsel Tatmin & 12 & 0,82 \\
\hline Dışsal Tatmin & 6 & 0,81 \\
\hline $\begin{array}{l}\text { Çok Boyutlu Iş̧ } \\
\text { Motivasyonu Ölçeği }\end{array}$ & 19 & 0,83 \\
\hline Motive Olamama & 3 & 0,80 \\
\hline Dışsal Düzenleme & 6 & 0,80 \\
\hline İçsel Düzenleme & 3 & 0,74 \\
\hline Kendine Yansıtma & 4 & 0,86 \\
\hline İçsel Motivasyon & 3 & 0,81 \\
\hline
\end{tabular}

Ölçüm aracının güvenilirlik katsayısı (Cronbach alfa değeri) $>0,50$ ise düşük düzeyde güvenilir, $>0,60$ ise güvenilirliği zayıf, $>0,70$ ise kabul edilebilir seviyede güvenilir, $>0,80$ ise oldukça güvenilir ve $>0,90$ ise yüksek derecede güvenilir olarak değerlendirilmektedir (Gliem \& Gliem, 2003: 87). Her iki ölçek ve alt boyutlarına ilişkin Cronbach alfa değerleri ölçüm araçlarının oldukça güvenilir olduğuna işaret etmektedir.

Güvenilirlik analizi sonrasında ölçüm araçları ve veriler için geçerlilik analizi yapılmıştır. Yapı geçerliliğini belirlemek için doğrulayıcı faktör analizinden (DFA) yararlanılmıştır. Bu çalışmada doğrulayıcı faktör analizi yöntemiyle yapılan yapısal geçerlilik analizleri için uyum indekslerinden yararlanılmıştır. Uyum indeksi değerlerinden Nisbi Ki-Kare değeri <3,0, RMSEA $\leq 0,05, \mathrm{CFI} \geq 0,95$, GFI $>0,95$, AGFI $>0,95$ ve SRMR $<0,05$ ise modelin iyi uyum gösterdiği değerlendirmesi yapılabilir (Schermelleh-Engel, Moosbrugger , \& Müller, 2003: 35-43). Yapılan uyum analizi sonucunda İş Tatmini ölçeğinde Nisbi Ki-Kare değeri 2,97, GFI 0,97, RMSEA 0,04, CFI 0,98, AGFI 0,96 ve SRMR değeri 0,05 elde edilmiştir. Ölçeğin Nisbi Ki-kare, GFI, RMSEA, CFI, AGFI ve SRMR değerleri iyi uyuma işaret etmektedir.

İş Motivasyonu ölçeğinde Nisbi Ki-kare değeri 2,13, GFI 0,99, RMSEA 0,02, CFI 1,00, AGFI 0,99 ve SRMR değeri 0,00 elde edilmiştir. Ölçeğin Nisbi Ki-kare, GFI, RMSEA, CFI, AGFI ve SRMR 
değerleri iyi uyuma işaret etmektedir. Söz konusu bulguların ölçüm aracının Norveççe, Almanca, Çince ve Malayca formları için elde edilen uyum indeksleriyle benzerlik gösterdiği söylenebilir (Gagné ve diğerleri, 2014:8).

\subsection{Hipotez Testi Bulguları}

Araştırmanın temel hipotezi "Çalışanların iş tatmini algıları ile iş motivasyonu düzeyleri arasında istatistiksel olarak anlamlı, doğrusal ve pozitif yönlü bir ilişki vardır” şeklinde belirlenmiştir. Araştırmanın temel hipotezi korelasyon analizi ile test edilmiştir. Araştırmada yaş, eğitim durumu ve iş deneyimi değişkenleriyle iş motivasyonu düzeyi arasındaki ilişkinin incelenmesinde ise tek yönlü varyans (ANOVA) analizinden yararlanılmıştır.

Analiz öncesinde verilerin korelasyon analizinin ön koşullarını karşılayıp karşılamadığ1 araştırılmıştır. Korelasyon analizinin önkoşulları doğrusallık, normallik ve değişkenlerin sürekliliği olmak üzere üç alt başlık halinde incelenmiş ve varsayımların karşılandığı görülmüştür. Değişkenler arasındaki korelasyon katsayılarının yer aldığı Tablo 2 incelendiğinde, iş tatmini ile iş motivasyonu ve alt boyutları arasında dışsal düzenleme dışında istatistiksel olarak anlamlı ve güçlü ilişkiler olduğu görülmektedir.

Tablo 2. iş Tatmini ve iş̧ Motivasyonu ile Alt Boyutlarına ilişsin Korelasyon Analizi Sonuçları

\begin{tabular}{|l|c|c|c|c|c|c|c|c|c|}
\hline & 1 & 2 & 3 & 4 & 5 & 6 & 7 & 8 & 9 \\
\hline 1. Iş̧ Tatmini & 1 & & & & & & & & \\
\hline 2. İçsel Tatmin &, $910^{* *}$ & 1 & & & & & & & \\
\hline 3. Dışsal Tatmin &, $845^{* *}$ &, $562^{* *}$ & 1 & & & & & & \\
\hline 4. İş Motivasyonu &, $577^{* *}$ &, $555^{* *}$ &, $440^{* *}$ & 1 & & & & & \\
\hline 5. Motive Olamama &, $327^{* *}$ &, $319^{* *}$ &, $229^{* *}$ &, $546^{* *}$ & 1 & & & & \\
\hline 6. DIşsal Düzenleme &, 118 &, 065 &, $160^{*}$ &, $458^{* *}$ &,- 089 & 1 & & & \\
\hline 7. İçsel Düzenleme &, $453^{* *}$ &, $409^{* *}$ &, $367^{* *}$ &, $790^{* *}$ &, $225^{* *}$ &, $380^{* *}$ & 1 & & \\
\hline 8. Kendine Yansıtma &, $522^{* *}$ &, $526^{* *}$ &, $365^{* *}$ &, $767^{* *}$ &, $335^{* *}$ &, $102^{*}$ &, $572^{* *}$ & 1 & \\
\hline 9. İçsel Motivasyon &, $476^{* *}$ &, $504^{* *}$ &, $328^{* *}$ &, $723^{* *}$ &, $193^{* *}$ &, $157^{*}$ &, $483^{* *}$ &, $552^{* *}$ & 1 \\
\hline
\end{tabular}

**. Korelasyon katsayıları $p<0.01$ düzeyinde anlamlıdır.

*. Korelasyon katsayıları $p<0.05$ düzeyinde anlamlıdır.

İş tatmini ile iş motivasyonu arasındaki ilişkiyi test etmeye yönelik SPPS v.23 aracılığıyla yapılan Pearson korelasyon analizi sonucunda, iki kavramsal yapı arasında istatistiksel açıdan anlamlı, doğrusal ve pozitif yönlü bir ilişki olduğu belirlenmiştir ( $\mathrm{r}=0,577 ; p=0,00, p<0,05)$. Buna göre çalışanların iş tatmini algıları arttıkça iş motivasyonu düzeylerinde de artış yaşanmaktadır. İş tatmini ile iş motivasyonu arasında orta düzeyde bir ilgileşim söz konusudur. İki kavramsal yapı arasındaki 
ilişkinin istatistiksel olarak anlamlı bulunmasıyla araşıtırmanın temel hipotezi doğrulanmıştır. $\mathrm{Bu}$ doğrultuda, sıfır hipotezinin reddedilmesinde başarı sağlanarak alternatif hipotez kabul edilmiştir.

Çalışmanın ikinci hipotezi "Yaş grupları ile iş motivasyonu düzeyi ortalama puanları arasında anlamlı bir farklılık olup olmadığını" belirlemeye yöneliktir. Analiz öncesinde tek yönlü varyans analizinin önkoşulları olan normallik, hataların bağımsızlığı ve eş varyanslılık varsayımları test edilmiş ve karşılandığı görülmüştür. Tek yönlü ANOVA analizi sonucunda, yaş bağımsız değişkeniyle iş motivasyonu sonuç değişkeni arasında istatistiksel olarak anlamlı bir ilişki olmadığı $(p=0,726)$ görülmüştür. İki değişken arasında anlamlı bir ilişki bulunmadığı için post-Hoc testi yapılmamıştır. Anlamlı bir ilişki belirlenemediği için alternatif hipotez reddedilerek $H_{0}$ kabul edilmiştir.

Tablo 3. Yaș Gruplarına ilișkin ANOVA Analizi Sonuçları

\begin{tabular}{lccccc}
\hline \hline & Kareler toplamı & $\begin{array}{c}\text { Serbestlik } \\
\text { derecesi }\end{array}$ & Kareler toplamı & F & Anlamlılık \\
\hline Gruplar &, 413 & 3 &, 138 &, 726 \\
arasında & 72,333 & 230 &, 314 & \\
Gruplar içinde & 72,747 & 233 & & \\
Toplam & & 338 & \\
\hline
\end{tabular}

Çalışmanın üçüncü hipotezi "Eğitim grupları ile iş motivasyonu düzeyi ortalama puanları arasında anlamlı bir farklılık olup olmadığını” belirlemeye yöneliktir. Analiz öncesinde tek yönlü varyans analizinin önkoşulları ilişkin varsayımlar test edilmiş ve karşılandığı görülmüştür. Tek yönlü ANOVA analizi sonucunda, eğitim bağımsız değişkeniyle iş motivasyonu sonuç değişkeni arasında istatistiksel olarak anlamlı bir ilişki olmadığ $(p=0,872)$ görülmüştür. İki değişken arasında anlamlı bir ilişki bulunmadığı için post-Hoc testi yapılmamıştır. Anlamlı bir ilişki belirlenemediği için alternatif hipotez reddedilerek $H_{0}$ kabul edilmiştir.

Tablo 4. Eğitim Gruplarına ilișkin ANOVA Analizi Sonuçları

\begin{tabular}{lccccc}
\hline \hline & Kareler toplamı & $\begin{array}{c}\text { Serbestlik } \\
\text { derecesi }\end{array}$ & Kareler toplamı & F & Anlamlılık \\
\hline Gruplar &, 223 & 3 &, 074 &, 235 &, 872 \\
arasında & 72,524 & 230 &, 315 & \\
Gruplar içinde & 72,747 & 233 & & \\
Toplam & & & & \\
\hline
\end{tabular}

Çalışmanın dördüncü hipotezi "iş deneyimi grupları ile iş motivasyonu düzeyi ortalama puanları arasında anlamlı bir farklılık olup olmadığını” belirlemeye yöneliktir. Analiz öncesinde tek yönlü varyans analizinin önkoşulları olan normallik, hataların bağımsızlığı ve eş varyanslılık varsayımları test edilmiş ve karşılandığı görülmüştür. Tek yönlü ANOVA analizi sonucunda, iş deneyimi bağımsız değişkeniyle iş motivasyonu sonuç değişkeni arasında istatistiksel olarak anlamlı bir ilişki olmadığı ( $p$ 
= 0,156) görülmüştür. İki değişken arasında anlamlı bir ilişki bulunmadığı için post-Hoc testi yapılmamıştır. Anlamlı bir ilişki belirlenemediği için alternatif hipotez reddedilerek $H_{0}$ kabul edilmiştir.

Tablo 5. İs Deneyimi Gruplarına îlişkin ANOVA Analizi Sonuçları

\begin{tabular}{lccccc}
\hline \hline & Kareler toplamı & $\begin{array}{r}\text { Serbestlik } \\
\text { derecesi }\end{array}$ & Kareler toplamı & F & Anlamlılık \\
\hline Gruplar & 2,073 & 4 &, 518 & 1,679 & \multirow{2}{*}{156} \\
arasında & 70,674 & 229 &, 309 & & \\
Gruplar içinde & 72,747 & 233 & & & \\
Toplam & & & & & \\
\hline
\end{tabular}

\section{Sonuç ve Tartışma}

Araştırma sonucunda çalışanların iş tatmini algılarıyla iş motivasyonu düzeyleri arasında anlamlı, doğrusal ve pozitif yönlü bir ilişki olduğu belirlenmiştir. Çalışanların iş tatmini algılarında artış gerçekleşmesi halinde iş motivasyonu düzeylerinde, dolayısıyla iş verimliliklerinde de olumlu etkilenme yaşanması beklenmektedir. Bu sonuç alan yazındaki bulgularla paralellik göstermektedir (Rasool, Jundong, \& Sohail, 2017: 122; Masvaure, Ruggunan, \& Maharaj, 2014: 494; Ogunnaike, Akinbola, \& Ojo, 2014: 200-201; Adeoye, Atiku, \& Fields, 2016: 32; Ayup \& Rafif, 2011: 339).

Demografik değişkenlerden yaş, eğitim durumu ve iş deneyimi ile iş motivasyonu arasında ise istatistiksel olarak anlamlı bir ilişki olmadığı sonucuna varılmıştır. Araştırmacılar tarafından yapılan çalışmalarda ise bu değişkenlerle iş motivasyonu arasında farklı bulgular elde edilmiştir. Alduaij'in araştırmasında yaş değişkeni ile iş motivasyonu arasında anlamlı bir ilişki olmadığı belirlenmiştir. (Alduaij, 2013: 187). Dündar, Özutku ve Taşpınar tarafından yapılan araştırmada yaş ve iş deneyimi grupları ile içsel/dışsal motivasyon araçları arasında anlamlı bir ilişki bulunamamıştır (Dündar, Özutku, \& Taşpınar, 2007: 115). İbicioğlu ve arkadaşlarının yaptığı araştırmada da yaş, eğitim ve iş deneyimi gruplarıyla katılımcıların motivasyon düzeyleri arasında anlamlı bir farklılık olmadığı belirlenmiştir. Wiyono tarafından yapılan çalışmada da benzer bir sonuç elde edilmiştir (İbicioğlu, Özdaşlı, Dalğar, \& Yılmaz, 2013: 101; Wiyono, 2016: 63-64). Saracel ve arkadaşları tarafindan yapılan çalışmada yaş grupları ile dışsal motivasyon arasında anlamlı bir farklılık olmadığı görülmüştür. Aynı araştırmada eğitim ve iş deneyimi ile dışsal motivasyon arasında ise anlamlı bir ilişki olduğu anlaşılmıştır. Lisans mezunu ve bir yıldan az deneyimi olan katılımcıların dışsal motivasyon puanlarının diğer gruplardan yüksek olduğu belirlenmiştir (Saracel, Taşseven, \& Kaynak, 2016: 66-71). Ağca ve Ertan tarafından yapılan araştırma da ise, iş görenlerin çalışma süresi arttıkça içsel motivasyonlarının yükseldiği sonucuna varılmıştır (Ağca \& Ertan, 2008: 149).

Araştırma sonuçları ve diğer çalışmalardaki bulgular göz önünde bulundurulduğunda işletme yöneticilerinin kurumsal hedeflerine ulaşabilmesi için çalışanların iş tatmini ve iş motivasyonu 
düzeylerini artırmaları gerektiği anlaşılmaktadır. Çalışanların beklentileri değerlendirilerek iş tatmini algıları ve iş motivasyonları olumlu yönde değiştirilebilir. Bireysel ihtiyaçların dikkate alınması, çalışma koşullarının iyileştirilmesi, ödüllendirme, kariyer imkânlarının sunulması ve adil ücret ücret mekanizmasının işletilmesi gibi yöntemler iş görenlerin iş tatmini ile iş motivasyonuna katkıda bulunacaktır. İş tatmini ve iş motivasyonu yüksek olan çalışanlar da, örgütsel performansın ve verimliliğin artmasında etkili olacaktır.

\subsection{Sonraki Araştırmalar İçin Öneriler}

Araştırmanın bulguları iş tatmini ile iş motivasyonu düzeyi arasında anlamlı, doğrusal ve pozitif yönlü bir ilişki olduğunu göstermektedir. Çalışanların iş tatmini algılarıyla iş motivasyonu düzeyleri arasındaki ilişkinin araştırıldığı bu çalışmada önemli bulgular tespit edilmesine karşın, araştırmanın bazı sınırlılıkları bulunmaktadır ve sonuçların bu çerçevede değerlendirilmesi gerekmektedir. Araştırma bulguları 234 çalışanın görüşleri ile sınırlıdır. Diğer bir sınırlılık ise, araştırma kapsamının Türkiye'de kimyevi gübre sektöründe üretici olarak faaliyet gösteren işletmelerde görev yapan beyaz yakalı çalışan ve yöneticilerden oluşmasıdır. Örneklem geniş tutularak diğer sektörler ve işletmelerde yapılacak araştırmalarda farklı sonuçlar elde edilebilir. 


\section{Kaynakça}

Adeoye, Abayomi Olarewaju, Sulaiman Olusegun Atiku ve Ziska Fields (2016) "Structural Determinants of Job Satisfaction: The Mutual Influences of Compensation Management and Employees' Motivation". Journal of Economics and Behavioral Studies, 8(5), 27-38.

Ağca, Veysel ve Hayrettin Ertan (2008) "Duygusal Bağlılık İçsel Motivasyon İlişkisi: Antalya'da Beş Yıldızlı Otellerde Bir İnceleme". Afyon Kocatepe Üniversitesi, İ.̇.B.F. Dergisi, 10(2), 135-156.

Alduaij, Hamad S. (2013) "A Study of Work Motivation among Kuwaiti Employees". International Journal of Business and Social Science, 4(10), 184-188.

Alonderiene, Raimonda ve Modesta Majauskaite (2016) "Leadership Style and Job Satisfaction in Higher Education Institutions". International Journal of Educational Management, 30(1), 140-164.

Ayup, Nadia ve Shagufta Rafif (2011) "The Relationship Between Work Motivation and Job Satisfaction". Pakistan Business Review, 13(2), 332-347.

Aziri, Birikend (2011) "Job Satisfaction: A Literature Review". Management Research and Practice, 3(4), 77-86.

Balıbey, Mesut ve Namık Kemal Öndaş (2018) "İdari Personelin Demografik Özellikleriyle İş Tatmini ve Mesleki Motivasyon İlişkisi: Munzur Üniversitesi Örneği". Fırat Üniversitesi Sosyal Bilimler Dergisi, 28(1), 171-186.

Beavers, Amy S., John W. Lounsbury, Jennifer K. Richards, Schuyler W. Huck, Gary J. Skolits ve Shelley L. Esquivel (2013) "Practical Considerations for Using Exploratory Factor Analysis in Educational Research". Practical Assessment, Research \& Evaluation, 18(6), 1-13.

Çivilidağ, Aydın ve Güçlü Şekercioğlu (2017) "Çok Boyutlu İş Motivasyonu Ölçeğinin Türk Kültürüne Uyarlanması". Mediterranean Journal of Humanities, 7(1), 143-156.

Dalkrani, Maria ve Efstathios Dimitriadis (2018) "The Effect of Job Satisfaction on Employee Commitment". International Journal of Business and Economic Sciences Applied Research, 11(3), 16-23.

Doğan, Selen ve Mecbure Aslan (2018) "Psikolojik Sermaye, İçsel Motivasyon ve İş Tatmini İlişkisi". Ömer Halisdemir Üniversitesi İktisadi ve İdari Bilimler Fakültesi Dergisi, 11(3), 112-125.

Dugguh, Stephen I. ve Dennis Ayaga (2014) "Job Satisfaction Theories: Traceability to Employee Performance in Organizations". IOSR Journal of Business and Management, 16(5), 11-18.

Dündar, Süleyman, Hatice Özutku ve Fatih Taşpınar (2007) "İçsel ve Dışsal Motivasyon Araçlarının İşgörenlerin Motivasyonu Üzerindeki Etkisi: Ampirik Bir İnceleme". Ticaret ve Turizm Eğitim Fakültesi Dergisi(2), 105-119.

Eğinli, Ayşen Temel (2009) "Çalışanlarda İş Doyumu: Kamu ve Özel Sektör Çalışanlarının İş Doyumuna Yönelik Bir Araştırma". Atatürk Üniversitesi İktisadi ve İdari Bilimler Dergisi, 23(3), 35-52.

Elias, Steven M., William, L. Smith ve Chet, E. Barney (2012) Age as a Moderator of attitude Towards Technology in the Workplace: Work Motivation and Overall Job Satisfaction. Behaviour \& Information Technology, 31(5), 453-467.

Eroğluer, Kemal (2011) "Örgütsel İletişim ile İş Tatmini Unsurları Arasındaki İlişkiler: Kuramsal Bir İnceleme". Ege Akademik Bakış, 11(1), 121-136.

Ertürk, Ramazan (2016) "Öğretmenlerin İş Motivasyonları". Eğitim Kuram ve Uygulama Araştırmaları Dergisi, 2(3), 1-15.

Fernet, Claude, Ste'phanie Austina ve Robert J. Vallerand (2012) "The Effects of Work Motivation on Employee Exhaustion and Commitment: An Extension of the JD-R Model". Work \& Stress, 26(3), 213-229.

Gagné, Maryléne ve Edward L. Deci (2005) "Self-determination Theory and Work Motivation". Journal of Organizational Behavior, 26, 331-362.

Gagné, Maryléne, Jacques Forest, Marie-Hélène Gilbert, Caroline Aubé, Estelle Morin ve Angela Malorni (2010) "The Motivation at Work Scale: Validation Evidence in Two Languages". Educational and Psychological Measurement, 70(4), 628-646.

Gagné, Maryléne, Jacques Forestb, Maarten Vansteenkistec, Laurence Crevier-Braudd, Anja Van den Broecke, Ann Kristin Aspelif, Jenny Belleroseg, Charles Benaboub, Emanuela Chemollia, Stefan Tomas Günterth, Hallgeir Halvarif, Devani Laksmi Indiyastutii, Peter A. Johnsonj, Marianne Hauan Molstadf, Mathias Naudink, Assane 
Ndaol, Anja Hagen Olafsenf, Patrice Rousselm, Zheni Wanga ve Cathrine Westbye (2014) "The Multidimensional Work Motivation Scale: Validation Evidence in Seven Languages and Nine Countries". European Journal of Work and Organizational Psychology, 1-19.

Gliem, Joseph A. ve Rosemary R. Gliem (2003) "Calculating, Interpreting, and Reporting Cronbach's Alpha Reliability Coefficient for Likert-Type Scales". Midwest Research to Practice Conference in Adult, Continuing, and Community Education (s. 82-88). Columbus: The Ohio State University.

Gökkaya, Samet ve Nuray Türker (2018) "İş Motivasyonu ile İş Tatmini Üzerine Otel İşletmelerinde Karşılaştırmalı Bir Araştırma". İktisadi İdari ve Siyasal Araştırmalar Dergisi, 3(5), 12-28.

İbicioğlu, Hasan, Kürşat Özdaşlı, Hüseyin Dalğar ve Tayfun Yılmaz (2013) "Muhasebe Meslek Mensuplarının İçsel ve Dışsal Motivasyon Düzeylerinin Tespitine Yönelik Bir Araştırma". Mehmet Akif Ersoy Üniversitesi Sosyal Bilimler Enstitüsü Dergisi, 5(9), 93-105.

Jungert, Tomas, Anja Van den Broeck , Bert Schreurs ve Ulla Osterman (2018) "How Colleagues Can Support Each Other's Needs and Motivation: An Intervention on Employee Work Motivation". Applied Psychology: An International Review, 67(1), 3-29.

Karaman, Davut (2018) "Demografik Özelliklerin İş Tatmini Üzerindeki Etkisi: Eğitim Sektöründe Bir Uygulama". Kırklareli Üniversitesi Sosyal Bilimler Dergisi, 2(1), 65-78.

Kaya, İlke (2007) "Otel İşletmeleri İşgörenlerinin İş Tatminini Etkileyen Faktörler: Geliştirilen Bir İş Tatmini Ölçeği". Anadolu Üniversitesi Sosyal Bilimler Dergisi, 7(2), 355-372.

Ledesma, Rubén Daniel ve Pedro Valero-Mora (2007) "Determining the Number of Factors to Retain in EFA: An Easy-to Use Computer Program for Carrying Out Parallel Analysis". Practical Assessment, Research \& Evaluation, 12(2), 1-11.

Li, Li, Hongyan Hu, Hao Zhou, Changzhi He, Lihua Fan, Xinyan Liu, Zhong Zhang, Heng Li ve Tao Sun (2014) "Work Stress, Work Motivation and Their Effects on Job Satisfaction in Community Health Workers: A Crosssectional Survey in China". BMJ Open, 4(6), 1-9.

Masvaure, Polite, Shaun Ruggunan ve A. Maharaj (2014) "Work Engagement, Intrinsic Motivation and Job Satisfaction Among Employees of a Diamond Mining Company in Zimbabwe". Journal of Economics and Behavioral Studies, 6(6), 488-499.

Matsunaga, Masaki (2010) "How to Factor- Analyze Your Data Right: Do's,Do'nts, and How-To's. International". Journal of Psychological Research, 3(1), 97-110.

Ogunnaike, Olaleke, Olufemi Akinbola ve Olugbenga Ojo (2014) "Effect of Motivation on Job Satisfaction of Selected Sales Representatives". Journal of Educational and Social Research, 4(1), 197-203.

Pinder, Craig C. (2014) Work Motivation in Organizational Behavior. New York: Psychology Press.

Rasool, Azhar, Hou Jundong ve Muhammad Tayyab Sohail (2017) "Relationship of Intrinsic and Extrinsic Rewards on Job Motivation and Job Satisfaction of Expatriates in China". Journal of Applied Sciences, 17, 116125.

Rigby, C. Scott ve Richard M. Ryan (2018) "Self-Determination Theory in Human Resource Development: New Directions and Practical Considerations". Advances in Developing Human Resources, 20(2), 133-147.

Ryan, Richard M. ve Edward L. Deci (2000) "Intrinsic and Extrinsic Motivations: Classic Definitions and New Directions". Contemporary Educational Psychology, 25, 54-67.

Saracel, Nüket, Özlem Taşseven ve Ece Kaynak (2016) "Türkiye’de Çalışan Y Kuşağında İş Tatmini-Motivasyon İlişkisi". Social Sciences Research Journal, 5(1), 50-79.

Schermelleh-Engel, Karin, Helfried Moosbrugger ve Hans Müller (2003) "Evaluating the Fit of Structural Equation Models: Tests of Significance and Descriptive Goodness-of-Fit Measures". Methods of Psychological Research Online, 8(2), 23-74.

Sdrolias, L., D. Belias, A. Koustelios, A. Golia, M. Koutiva, A. Thomos ve K. Varsanis (2014) "Job Satisfaction and Motivation in the Greek Banking Sector". 9th Annual MIBES International Conference (s. 82-101). Thessaloniki: Perrotis College.

Seifert, Tricia A. ve Paul D. Umbach (2008) "The Effects of Faculty Demographic Characteristics and Disciplinary Context on Dimensions of Job Satisfaction". Research in Higher Education, 49(4), 357-381. 
Seyrek, İbrahim Halil ve Dilek Kavak (2016) "Bilgi Teknolojisi Çalışanlarının İş Tatmini ile İlişkili Faktörler". Optimum Ekonomi ve Yönetim Bilimleri Dergisi, 3(1), 13-27.

Spector, Paul E. (1985) "Measurement of Human Service Staff Satisfaction: Development of the Job Satisfaction Survey". American Journal of Community Psychology, 13(6), 693-713.

Springer, Gary Jon (2011) A Study of Job Motivation, Satisfaction, and Performance among Bank Employees. The Journal of Global Business Issues, 5(1), 29-42.

Sultan, S. (2012). Examining the Job Characteristics: A Matter of Employees' Work Motivation and Job Satisfaction. Journal of Behavioural Sciences, 22(2), 13-25.

Weiss, Howard M. (2002) "Deconstructing Job Satisfaction: Separating Evaluations, Beliefs and Affective Experiences". Human Resource Management Review, 12(2), 173-194.

Wiyono, Bambang Budi (2016) "Comparation of Teachers' Work Motivation Based on Gender, Age, Education Level, Work Duration, Rank and School Level". Journal of Education and Social Sciences, 3, 61-66. 